\title{
Psychological Structure of Future Psychologists' Professional Competence
}

\section{Психологічна структура професійної компетентності майбутніх психологів}

\author{
Nataliia Perehonchuk \\ Ph.D. in Psychology, \\ Assistant Professor of the \\ Department of Psychology \\ and Social Work
}

\author{
Наталія Перегончук \\ кандидат психологічних \\ наук, доцент кафедри \\ психології та соціальної \\ роботи
}
E-mail: nataliaperegoncuk@gmail.com orcid.org/0000-0001-5965-5288
Researcher ID: C-4066-2019

Вінницький педагогічний університет ілені Михайла Коцюбинського, м. Вінниия, Украӥна вул. Острозького, 32, м. Вінниця, 21100

Original manuscript received December 11, 2018

Revised manuscript accepted January 25, 2019

\section{ABSTRACT}

The empirical study of the psychological structure of future psychologists' professional competence is presented in the article. The development of professional competence is characterized as a dynamic process which mobilizes the external and internal resources in unpredictable conditions of everyday life.

The study involved the students of Vinnytsia Mykhailo Kotsiubynskyi State Pedagogical University, National Pedagogical Dragomanov University and Borys Grinchenko Kyiv University, a total of 546 students. 
In order to evaluate and measure the components of the structure of professional competence of future psychologists, it is used in view of the definition of this concept and approaches to its study.

In order to determine the place, role and significance of each component that may act as a determinant of this process, factor analysis was performed through the main components method with Varimax raw rotation.

On the basis of factor analysis, the psychological structure of professional competence has been revealed as including motivational-value, operationalconative, emotional-regulatory, reflexive-cognitive components.

The greatest semantic meaning was attributed to a factor called "motivational and value». This factor includes indicators that reflect life and career orientations, strivings for success and self-realization in future profession. The second component, called "operational and conative», includes indicators which reflect desire for changes. The third factor, "emotional and regulatory", reflects the emotional and volitional activity of a student and includes indicators of emotional intellect and self-regulation of a personality in new situations. The fourth component, "reflexive and cognitive», includes intellectual involvement in the process of mastering future professional activities via the interest in knowledge, modeling and planning of one's activities based on available knowledge and readiness for the acquisition of new knowledge.

Key words: professional competence, future psychologists, motivational and value, operational and conative, emotional and regulative, reflexive and cognitive components, psychological structure.

\section{Вступ}

Модернізація системи професійної підготовки майбутніх психологів спрямована на розвиток їх компетентності в аспекті зростаючих потреб до самостійності, відповідальності, вміння взаємодіяти з іншими людыми.

Професійна компетентність майбутніх психологів як комплексний ресурс особистості забезпечує можливість ефективної взаємодії у професійному просторі та навколишньому світі й залежить від необхідності набуття для цього професійних компетентностей. Вимоги до профресійної компетентності, представлені у профілі майбутнього фахівця, включають комплекс професійних компетентностей, котрі необхідно сформувати у студентів за спеціальністю і програмою вищої освіти. На сьогодні затребу- 
ваним є фахівець, який швидко і якісно вирішує поставлені завдання, володіє професійними компетентностями, ініціативний, з добре розвиненими вольовими якостями, володіє емоційною стійкістю, здатний до творчого підходу в діяльності, ефективного використання своїх можливостей, прагне до професійного саморозвитку і самовдосконалення.

На думку М. Чошанова, «компетентність - принципово нова якість професійної підготовки». Науковець вважає, що компетентність як специфічна якість сукупності професійних знань і вмінь виражається у таких показниках: 1) компетентна людина постійно оновлює свої знання i вони є оперативними та мобільними; 2) компетентність припускає вміння обирати оптимальні рішення, аргументувати вибір, відкидати помилкові шляхи, тобто мати критичність мислення; 3) компетентність включає як змістовий - знання, так і процесуальний - уміння, компоненти (Чошанова, 1997).

У науковій праці «Оцінка професійної компетентності» професор Вісконсинського університету M. Кейн (Michael T. Kane) підкреслює, що «детальна розробка структурних компонентів професійної компетентності забезпечує можливості для адекватної оцінки її набутого рівня». На думку автора, чітке структурування професійної компетентності - надскладне завдання, складність якого безпосередньо пов'язана з неоднозначністю самого поняття, оцінкою їі рівнів і можливістю вимірювання та прогнозування (Kane, 2013).

Т. Соколова (Брестський університет, Республіка Білорусь) пріоритетне місце у структурі професійної компетентності відводить мотиваційному компоненту, що є можливим винятково за умови зростання внутрішньої мотивації фахівців за рахунок активної та проактивної позиції в професійній діяльності. Поняття «професійна компетентність» розкривається крізь призму поняття «професійна спрямованість». Дослідниця констатує, що «професійна 
компетентність є системою переважаючих мотивів у професійній діяльності, ціннісних орієнтацій, інтересів і професійних намірів» (Соколова, 2015).

Продовженням розробок у цьому напрямку є праця колективу американських дослідників на чолі з К. Елісоном (Kevin W. Allison) «Людська різноманітність і професійна компетентність», предметом якої є проблема набуття професійної компетентності майбутніми психологами. На думку авторів, професійна компетентність майбутнього психолога повинна включати різні компоненти, залежно від того, наприклад, із якими групами населення психолог працюватиме в майбутньому, а запорукою цього є застосування тренінгових технологій навчання майбутніх фахівців-психологів (Allisson, 2014).

Психологічними умовами розвитку професійної компетентності майбутніх психологів Н. В. Перегончук вважає освітній простір, розкриваючи його можливості, зокрема: освітній простір є не тільки джерелом інформації, а можливістю для саморозвитку; актуалізує потребу для постійного оновлення знань (неперервна освіта, освіта впродовж усього життя і в різних інституціях - формальна, неформальна, інформальна); освітній простір стає особистісно усвідомленим (мотиви, цінності, орієнтації, потреби) й особистісно зорієнтованим (професійний та особистісний розвиток, оптимізація особистісного потенціалу); актуалізує активність майбутнього психолога; розширюе межі навчального діалогу, що сприяє формуванню професійно важливих якостей майбутнього психолога (рефлексія, самопізнання, самоконструювання) (Peregonchuk, 2016).

Незважаючи на велику кількість досліджень, у зарубіжній науковій традиції не вироблено єдиних підходів до оцінки та вимірювання професійної компетентності майбутніх психологів. Створений зарубіжними авторами вимірювальний інструментарій - це особистісні опитувальники, що відображають різноманітність у розумінні сутності цього явища. Українські дослідники використовують 
теоретично обгрунтовані й апробовані психодіагностичні комплекси, спрямовані на вивчення різних психологічних аспектів професійної компетентності, виходячи з визначення цього поняття та підходів до його дослідження.

Ураховуючи, що дослідження професійної компетентності пов' язано з труднощами визначення єдиного розуміння самого поняття, його структурних компонентів і системи їх взаємозв'язку, можна констатувати про неузгодженість вимірювального інструментарію. Ці чинники потребують нового змісту методичної бази експериментального дослідження розвитку професійної компетентності майбутніх психологів. Отже, визначення і теоретичне обгрунтування методичної бази дослідження розвитку професійної компетентності майбутніх психологів є актуальним і потребує науково обгрунтованого підходу (Peregonchuk, 2018).

Мета статті - висвітлити й обгрунтувати результати емпіричного дослідження психологічної структури професійної компетентності майбутніх психологів.

\section{Завдання дослідження}

Провести факторний аналіз професійної компетентності майбутніх психологів і на основі отриманих результатів визначити значущі структурні компоненти.

\section{Методи і методики дослідження}

У процесі теоретичного вивчення проблеми та науковоекспериментальної роботи використовувалися як загальнонаукові, так і спеціальні методи дослідження:

а) теоретичні - аналіз наукової літератури, узагальнення отриманої інформації, системний аналіз та інтерпретація емпіричних даних, класифікація, структурно-динамічне моделювання;

б) емпіричні - опитувальник «Діагностика емоційного інтелекту» Н. Холла (Фетіскін, 2002), методика «Стильова саморегуляція поведінки людини» В. І. Моросанової та Є. М. Коноз (Моросанова, 2000), опитувальник самоорга- 
нізації діяльності Е. Ю. Мандрикової (Фетіскін, 2002), методика «Особистісна готовність до змін» (автори: Роднік, Хезер, Голд, Хал; адаптація: Н. А. Бажанова, Г. Л. Бардієр) (Фетіскін, 2002), опитувальник «Як ви ставитеся до змін?» К. Фрайлінгера й I. Фішера (Фрайлінгер, 2002), діагностика самоактуалізації особистості А. В. Лазукіна в адаптації Н. Ф. Каліна (Фетіскін, 2002), методика соціально-психологічної активності особистості (Фетіскін, 2002), Експрес-діагностика особистісної конкурентоздатності Н. П. Фетіскіна, В. В. Козлова, М. Г. Мануйлова (Фетіскін, 2002), Тест смисложиттєвих орієнтацій (СЖО) Д. О. Леонтьєва (Леонтьев, 2000), опитувальник «Прагнення до змін » Д. О. Леонтьєва і Д. В. Сапронова (Сапронов \& Леонтьев, 2007), «Діагностика мотиваційної структури особистості» В. С. Мільмана (Фетіскін, 2002), методика діагностики ціннісних орієнтацій в кар’єрі «Якорі кар’єри» Е. Шейна, переклад і адаптація В. Чікер і В. Винокурової (Фетіскін, 2002), "Діагностика реалізації потреби в саморозвитку» Н. П. Фетіскіна (Фетіскін, 2002), методика діагностики рефлексивності А. В. Карпова (Фетіскін, 2002), опитувальник «Диференційний тип рефлексії Д. О. Леонтьєва та Є. М. Осіна (Леонтьєв \& Осін, 2014);

в) методи математичної статистики (факторний аналіз), що забезпечує якісний і кількісний аналіз результатів. Емпіричні дані, отримані в ході дослідження, піддавалися статистичній обробці за допомогою спеціалізованого пакету прикладних програм для психологічних досліджень «SPSS-17.0», що забезпечуе виконання загальноприйнятих одномірних статистик і багатомірних математико-статистичних методів.

\section{Результати дослідження}

Дослідження проводилось упродовж 2017-2018 навчального року. Респондентами виступили 546 студентів I-IV курсів і магістратури Вінницького державного педагогічного університету імені Михайла Коцюбинського 
(спеціальність «Психологія»), Національного педагогічного університету імені М. П. Драгоманова (спеціальність «Психологія») та Київського університету імені Бориса Грінченка (спеціальність «Психологія»).

Для визначення місця, ролі та ваги кожного структурного компонента професійної компетентності майбутніх психологів, що можуть виступати як детермінанти їх розвитку, нами був проведений факторний аналіз методом головних компонентів із Varimax raw обертанням. Це дало змогу виокремити основні компоненти психологічної структури професійної компетентності, що виступають у ролі визначальних одиниць процесу їі розвитку.

Перший фактор пояснює $32,58 \%$ загальної дисперсії і включає такі показники професійної компетентності, як професійна компетентність $(0,865)$, прагнення до успіху $(0,857)$, цілі життя $(0,821)$, конкурентоздатність $(0,809)$, цінності $(0,737)$, потреба у пізнанні $(0,719)$, самомотивація $(0,719)$, мотиваційний профіль особистості $(0,7)$, прагнення до змін $(0,662)$, результат життя $(0,655)$, соціальний статус $(0,551)$, прагнення до влади $(-0,54)$, автономія $(0,52)$, процес життя $(0,509)$, інтеграція стилів життя $(0,492)$, соціальна користь $(0,483)$, служіння $(0,465)$, виклик $(0,391)$, творча активність $(0,389)$, стабільність $(0,381)$, життєзабезпечення $(0,363)$, комфорт $(0,351)$, спілкування $(0,326)$, менеджмент $(0,297)$ і підприємництво $(-0,287)$. Вивчення змісту означеного фактора дало змогу позначити його як мотиваційно-ціннісний компонент професійної компетентності майбутніх психологів.

Другий фактор пояснює 22,73\% загальної дисперсії. Його зміст складають такі показники, як толерантність до двозначності $(0,994)$, контроль $(-0,927)$, автономність $(0,883)$, прийняття ризику $(0,874)$, адаптивність $(0,829)$, тип ставлення до змін (вільнодумець $(0,733)$, реаліст $(0,669)$ і традиціоналіст $(-0,559))$, спонтанність $(0,682)$, винахідливість $(0,624)$, залученість $(0,583)$, упевненість $(0,531)$, креативність $(0,496)$, загальна активність $(0,488)$, 
гнучкість у спілкуванні $(0,401)$, контактність $(0,391)$, сміливість $(0,348)$, пристрасність $(0,347)$, орієнтація в часі $(0,295)$ і погляд на природу людини $(0,255)$. Якісний аналіз цього фактора дав змогу позначити його як операційноконативний компонент професійної компетентності майбутніх психологів.

Третій фактор охоплює $11,2 \%$ загальної дисперсії. Аналіз показників, які утворюють цей фактор, дав підставу назвати його емоційно-регулятивним компонентом професійної компетентності майбутніх психологів. Він включає емоційну усвідомленість $(0,868)$, управління власними емоціями $(0,705)$, розпізнавання емоцій інших $(0,648)$, загальний рівень саморегуляції $(0,627)$, аутосимпатію $(0,604)$, самоорганізацію $(0,6)$, локус контролю «Я» $(0,592)$, цілеспрямованість $(0,536)$, емпатію $(0,513)$, планомірність $(0,499)$, локус контролю життя $(0,426)$, наполегливість $(0,393)$, орієнтацію на теперішне $(0,362)$, самостійність $(0,274)$, оптимізм $(0,348)$ і фіксацію $(-0,305)$.

Рефлексивно-когнітивним компонентом професійної компетентності майбутніх психологів було названо четвертий фактор, який охоплював 7,86\% загальної дисперсії. Його зміст утворювали такі показники, як рефлективність $(0,57)$, когнітивний профіль особистості $(0,554)$, системна рефлексія $(0,537)$, саморозуміння $(0,533)$, інтроспекція $(0,48)$, оцінка результату $(0,464)$, квазірефлексія $(-0,427)$, осмисленість життя $(0,423)$, планування $(0,318)$, програмування $(0,275)$, моделювання $(0,241)$ і гнучкість $(-0,35)$.

Отже, за результатами факторного аналізу, професійна компетентність за «мотиваційно-ціннісним» типом передбачає розвиненість осмислення майбутнім фахівцем цінності професійної компетентності та наявного досвіду і розвиток на їх основі професійних орієнтирів. За нових соціально-економічних обставин важливо не тільки сформувати певні професійні знання, вміння і навички, але й реалізовувати їх в умовах високої конкурентності, надаючи перевагу смисложиттєвим і кар'єрним цінностям. ЗЖит- 
тєві цілі майбутніх психологів є осмисленими і цілеспрямованими, орієнтовані на досягнення успіху, що властиво самоактуалізуючій особистості.

В основі професійної компетентності за «операційноконативним» типом лежать готовність пізнавати нове, творчо самовиражатися, перетворюючи себе й навколишній світ, і мобілізація особистістю власного потенціалу для виходу за межі відомого, випробуваного й опанування на цій основі новим досвідом. Цей чинник відображає, переважно, динамічні характеристики професійної компетентності - готовність до змін як саморух особистості до самовдосконалення та саморозвитку. Внутрішнім змістом готовності до змін виступає загальна активність студента в реалізації життєвих і професійних перспектив.

Професійна компетентність за «емоційно-регулятивним» типом відображає емоційно-вольову активність студента, що включає емоційність як позитивний емоційний чинник (реакцію на успіх і невдачу) й емотивність (ціннісний показник усвідомлення суб'єктом необхідності професійної діяльності), позитивно емоційно забарвлене ставлення до особистісного і професійного самовдосконалення (оптимізм і самостійність у нових ситуаціях навчальної діяльності, наполегливість у досягненні поставлених цілей). Основним показником цього чинника є здатність до усвідомлення емоцій - як власних, так і інших людей, орієнтація на теперішнє «тут і тепер», саморегуляція та самоорганізація в динамічних і непередбачуваних умовах повсякденного життя.

Професійна компетентність за «рефлексивно-когнітивним» типом передбачає здатність сприймати навчальну інформацію та наявність певного «багажу» знань. Основними складовими компонента є інтелектуальна залученість у процес оволодіння майбутньою професійною діяльністю через інтерес до знань, моделювання та планування своєї діяльності на основі наявних знань і відкритість до набуття 
нових знань. Важливими показниками цього типу професійної компетентності є осмисленість майбутніми психологами власних дій та оцінка набутого досвіду.

Для визначення рівнів розвитку компонентів професійної компетентності кожного окремого досліджуваного нами була проведена процедура стандартизації. За кожним фактором були обчислені описові статистики факторів, зокрема медіана (Me) і стандартне відхилення ( $\sigma)$ та інші, які дали змогу визначити рівні компонентів професійної компетентності майбутніх психологів. Межі середнього рівня визначались за формулою $\mathrm{Me} \pm 1 / 2 \sigma$. Так, для фактора 1 медіана (Me) становила -0,056, для фактора $2-0,396$, для фактора $3--0,008$, для фактора $4-0,026$. Стандартне відхилення $\sigma$ для всіх факторів становило 1. Отже, середній рівень фактора 1 має межі від -1,029 до 0,362; фактора 2 від -1,059 до 0,843, фактора 3 - від $-0,553$ до 0,428; фактора 4 - від $-0,431$ до 0,431 .

Таблиця 1. Рівні розвитку компонентів професійної компетентності майбутніх психологів (у \%)

\begin{tabular}{|c|c|c|c|c|c|c|c|}
\hline \multirow{3}{*}{$\begin{array}{c}\text { № } \\
3 / \Pi\end{array}$} & \multirow{3}{*}{ Компонент } & \multicolumn{6}{|c|}{ Рівні } \\
\hline & & \multicolumn{2}{|c|}{ Низький } & \multicolumn{2}{|c|}{ Середній } & \multicolumn{2}{|c|}{ Високий } \\
\hline & & $\mathbf{N}$ & $\%$ & $\mathbf{N}$ & $\%$ & $\mathbf{N}$ & $\%$ \\
\hline 1. & Мотиваційно-ціннісний & 69 & 12,64 & 295 & 54,03 & 182 & 33,33 \\
\hline 2. & Операційно-конативний & 108 & 19,78 & 341 & 62,45 & 97 & 17,77 \\
\hline 3. & Емоційно-регулятивний & 125 & 22,89 & 264 & 48,35 & 157 & 28,75 \\
\hline 4. & Рефлексивно-когнітивний & 153 & 28,02 & 241 & 44,14 & 152 & 27,84 \\
\hline
\end{tabular}

Обчислення рівнів розвитку компонентів професійної компетентності майбутніх психологів (табл. 1) дозволило дійти висновку, що низький рівень мотиваційно-ціннісного компонента притаманний $12,64 \%$ досліджуваних. Ceредній рівень означеного компонента властивий більшості досліджуваних $(54,03 \%)$, а третина з них має високий рівень його розвитку $(33,33 \%)$. 
Отримані результати вказують на той факт, що для студентів є значущими професійні потреби, мотиви і цінності діяльності, що формуються на тлі стійкого інтересу і позитивного ставлення до майбутньої професії. Високий рівень розвитку цього компонента вказує на усвідомлення студентами соціальної значущості майбутньої професії, ставлення до себе як до майбутнього професіонала, мотивацію на діяльність, саморозвиток, самовдосконалення і кар'єру . Саме мотивація майбутніх психологів задає вектор розвитку професійної компетентності та прагнення до створення успішної кар'єри. Тобто, такі студенти відповідально ставляться до свого майбутнього, мають цілі, співставні 3 їх власною системою смисложиттєвих орієнтацій, розуміють потребу в пізнанні та постійному оновленні знань, приймають виклик життя («виклик») як можливість здобуття нового досвіду («прагнення до змін»), орієнтуючись на сучасний динамічний світ, усвідомлюють значущість майбутньої професії не тільки для себе як професіонала, але і для суспільства («соціальна користь», «служіння»). Майбутню професію розглядають як спосіб організації заробітку, проявляють творчу активність у професійній реалізації, залучають інших людей для досягнення поставлених цілей.

Середній рівень притаманний половині досліджуваних і відображає недостатню сформованість мотивів і цінностей майбутніх психологів. Очевидно, такі студенти не задумуються над цілями свого життя, не розуміють свого місця в майбутній професії через відсутність ідеалів і цінностей, прагнень, планів на життя, а тому не зорієнтовані на досягнення професійного успіху й побудову успішної кар'єри.

Низький рівень мотиваційно-ціннісного компонента в досліджуваних указує на відсутність їх орієнтації на досягнення успіхів у майбутній професії. У таких студентів труднощі у навчанні викликають страх і невдоволення, у них відсутні плани на життя, ідеали та цінності, оскільки вони бояться змін і ризиків, не вбачають перспектив у обраній професії. 
Аналіз результатів обчислення операційно-конативного компонента професійної компетентності майбутніх психологів засвідчив, що 19,78\% опитаних мають низький його рівень, 62,45\% - середній, а 17,77\% - високий рівень розвитку.

Про сформованість у студентів високого рівня розвитку операційно-конативного компонента свідчать: внутрішня готовність до застосування набутих знань у практичній діяльності, готовність до змін; уміння знаходити вихід зі складних ситуацій, звертатися до нових джерел для вирішення проблем; прагнення до нового, невідомого, відмова від раніше випробуваних і надійних способів дій у стресових ситуаціях, що відповідає толерантності до двозначності; уміння змінювати свої плани і рішення, перебудовуватися в нових ситуаціях, не наполягати на своєму, якщо цього вимагає ситуація; віра в себе, у свої чесноти i свої сили діяти в невизначених ситуаціях; уміння впоратися з мотиваційними й емоційними «силами», що конфліктують, у ситуації вибору; орієнтація на теперішне; довіра своїм відчуттям тощо.

До групи із середнім рівнем розвитку операційно-конативного компонента належать студенти, у яких недостатньо сформовані такі показники, як готовність до змін, толерантність до двозначності, прийняття ризику, гнучкість у спілкуванні та загальна активність.

Про низький рівень розвитку операційно-конативного компонента свідчать нездатність відмовитися від старих порядків і звичаїв, неприйняття невизначених і передбачуваних ситуацій, небажання звертатися по допомогу та відсутність активності у нових і динамічних умовах життя, неготовність проявляти компетентність, а також відсутність бажання реалізовувати свої плани, задуми.

Вивчення розподілу рівнів емоційно-регулятивного компонента професійної компетентності виявило, що низький його рівень мають 22,89\% студентів, середній $48,35 \%$, а високий $-28,75 \%$ досліджуваних. 
До групи з високим рівнем розвитку емоційно-регулятивного компонента належать студенти, які вміють управляти своїми емоціями, розпізнають емоції інших, володіють саморегуляцією. Такі студенти проявляють оптимізм у ситуації труднощів і випробувань, вони цілеспрямовані й крок за кроком ідуть до своєї мети, опираючись на свої сильні сторони, організовуються до реалізації намічених планів самостійно і можуть залучати інших до цього процесу. До групи із середнім рівнем розвитку емоційно-регулятивного компонента належать ті майбутні психологи, у яких недостатньо сформовані емпатія, навички саморегуляції та самоорганізації.

До групи з низьким рівнем емоційно-регулятивного компонента належать студенти, яким важко управляти своїми емоціями та розпізнавати емоції інших, у ситуаціях труднощів вони не здатні демонструвати витримку і самоконтроль, не сформовані навички саморегуляції.

$28,02 \%$ майбутніх психологів мають низький рівень розвитку рефлексивно-когнітивного компонента професійної компетентності, що може негативно позначитись на їх майбутній професійній діяльності.

До групи з високим рівнем розвитку рефлексивно-когнітивного компонента належать студенти, які здатні до планування та моделювання власної діяльності, осмислено ставляться до життя, чутливі та сенситивні до своїх бажань і потреб, не схильні підміняти власні смаки й оцінки зовнішніми соціальними стандартами, здатні зосереджуватись на власному стані та переживаннях, мають сформований чіткий образ професійного майбутнього, усвідомлюють цінність прагнення до самовдосконалення.

До групи із середнім рівнем розвитку рефлексивнокогнітивного компонента професійної компетентності належать студенти, у яких недостатньо сформовані вміння свідомо контролювати результати своєї діяльності, рівень свого розвитку й особистих досягнень. 
До групи з низьким рівнем рефлексивно-когнітивного компонента належать студенти, у яких відсутні схильність до осмислення дій суб'єкта, самоорганізація, рух через самопізнання, самоаналіз себе, свого стану - внутрішніх психічних актів, власних форм і передумов, своєї розумової діяльності, цілісного «Я». Такі студенти не орієнтовані на самопізнання, самовдосконалення та саморозвиток.

Отже, проведений аналіз емпіричних даних за допомогою факторного аналізу дав нам змогу визначити такі чотири фактори, як: мотиваційно-ціннісний, операційноконативний, емоційно-регулятивний, рефлексивно-когнітивний. Найбільше смислове навантаження отримав мотиваційно-ціннісний фактор. Усвідомлення значущості поняття професійної компетентності майбутнього фахівця, розуміння її суті та структури сприятиме не тільки удосконаленню навчально-виховного процесу, а також підтримці його професійної кваліфікації відповідно до науково-технічного і соціально-економічного прогресу суспільства.

\section{Висновки}

Проблема розвитку професійної компетентності майбутніх психологів повинна розв'язуватися, насамперед, шляхом вивчення тих особистісних структур, що забезпечують високий рівень результативності й ефективності діяльності в сучасних динамічних умовах життя. Прагнення до професійної самореалізації розвивається тільки у разі особистого прийняття й усвідомлення цілей і завдань майбутньої професії, що в підсумку призводить до розвитку ініціативи, готовності до творчості, повного розкриття потенціалу особистості.

Виокремлено й операціоналізовано складові структури професійної компетентності майбутніх психологів в умовах сучасного соціуму: мотиваційно-ціннісний, операційно-конативний, емоційно-регулятивний, рефлексивнокогнітивний. Кожен компонент професійної компетентності відіграє важливу роль у структурі, а їх взаємозв’язок 
спрятиме досягненню успіху в діяльності та професіоналізму майбутніх психологів.

\section{Література}

Леонтьев Д. А. Тест смысложизненных ориентаций (СЖЖO). 2-е изд. Москва : Смысл, 2000. 18 с.

Леонтьев Д. А., Осин Е. Н. Рефлексия «хорошая» и «дурная»: от объяснительной модели к дифференциальной диагностике. Психология. Журнал Высшей школы эконолики. 2014. № 4. С. 110-135.

Моросанова В. И. Стилевая саморегуляция поведения человека. Вопросы психологии. 2000. № 2. С. 118-126.

Перегончук Н. В. Формування професійної компетентності майбутніх психологів у сучасному освітньому просторі. Наука і освіта. 2016. № 11. С. 49-55.

Сапронов Д. В., Леонтьев Д. А. Личностный динамизм и его диагностика. Психологическая диагностика. 2007. № 1. С. 66-68.

Соколова Т. В. Мотивационная сфера личности как компонент ее профессиональной направленности [Электронный ресурс]. Режим доступа : http://lib.brsu.by/sites/default/files/Мотивационная cфpepa.pdf.

Фетискин Н. П., Козлов В. В., Мануйлов Г. М. Социально-психологическая диагностика развития личности и малых групп. Москва : Изд-во Института психотерапии, 2002. С. 57-59.

Фрайлингер К. Управление изменениями в организации. Москва : Книгописная палата, 2002. 264 с.

Чошанов М. П. Дидактическое конструирование гибкой технологии обучения. Педагогика. 1997. № 2. С. 21-27.

Allison, K. W. (2014). Human diversity and professional competence: Training in clinical and counselling psychology revisited. Retrieved from http://psycnet.apa.org/journals/amp/49/9/792/

Kane, M. T. (2013). The Assessment of Professional Competence. Retrieved from http://ehp.sagepub.com/content/15/2/163.short.

Peregoncuk, N. V. (2018). Development trend in pedagogical and psychological science the experience of countries of Eastern Europe and prospects of Ukraine. Development model of professional competence of future psychologists: monograph. Riga, Latvia. P. 151-170.

\section{References}

Leont'ev, D. A. (2000). Test smyslozhiznennyh orientacij (SZhO) [Test on the meaning of life orientation (LSS)] (2nd ed.). Moskwa : Smysl [in Russian].

Leont'ev, D. A., \& Osin, Je. N. (2014). Refleksija «horoshaja» i «durnaja» : ot ob'jasnitel'noj modeli k differencial'noj diagnostike [Reflection 
of «good» and «bad»: from the explanatory model to the differential diagnosis]. Psihologija. Zhurnal Vysshej shkoly jekonomiki-Psychology. Journal of the Higher School of Economics, 4, 110-135 [in Russian].

Morosanova, V. I. (2000). Stilevaja samoreguljacija povedenija cheloveka [Style self-regulation of human behavior]. Voprosy psyhologii-Psychology issues, 2, 118-126 [in Russian].

Perehonchuk, N. V. (2016). Formuvannia profesiinoi kompetentnosti maibutnikh psykholohiv u suchasnomu osvitnomu prostori [Formation of professional competence of future psychologists in the modern educational space]. Nauka ta osvita-Science and education, 11, 49-55 [in Ukrainian].

Sapronov, D. V., \& Leont'ev, D. A. (2007). Lichnostnyj dinamizm i ego diagnostika [Personal dynamism and its diagnosis]. Psihologicheskaja diagnostika - Psychological diagnosis, 1, 66-68 [in Russian].

Sokolova, T. V. (2015). Motivacionnaja sfera lichnosti kak komponent eje professional'noj napravlennosti [The motivational sphere of the personality as a component of its professional orientation]. Retrieved from http://lib.brsu.by/sites/default/files/Motivational sphere.pdf [in Russian].

Fetiskin, N. P., Kozlov, V. V., \& Manujlov, G. M. (2002). Social'no-psihologicheskaja diagnostika razvitija lichnosti i malyh grupp [Social and psychological diagnosis of personal development and small groups]. Moskwa : Isd-vo Instituta psychoterapii [in Russian].

Frajlinger, K. (2002). Upravlenie izmenenijami v organizacii [Management of changes in the organization ]. Moskwa : Knigopisnaja palata [in Russian].

Choshanov, M. P. (1997). Didakticheskoe konstruirovanie gibkoj tehnologii obuchenija [Didactic constructing of flexible technology of training]. Pedagogika-Pedagogics, 2, 21-27 [in Russian].

Allison, K. W. (2014). Human diversity and professional competence: Training in clinical and counselling psychology revisited. Retrieved from http://psycnet.apa.org/journals/amp/49/9/792/

Kane, M. T. (2013). The Assessment of Professional Competence. Retrieved from http://ehp.sagepub.com/content/15/2/163.short.

Peregoncuk, N. V. (2018). Development trend in pedagogical and psychological science the experience of countries of Eastern Europe and prospects of Ukraine. Development model of professional competence of future psychologists: monograph. Riga, Latvia. P. 151-170.

\section{АНОТАЦІЯ}

У статті представлено емпіричне дослідження психологічної структури професійної компетентності майбутніх психологів. Охаракте- 
ризовано розвиток професійної компетентності як динамічний процес мобілізації зовнішніх і внутрішніх ресурсів у непередбачуваних умовах повсякденного життя.

У дослідженні взяли участь 546 студентів Вінницького державного педагогічного університету імені Михайла Коцюбинського, Національного педагогічного університету імені М. П. Драгоманова та Київського університету імені Бориса Грінченка.

Оцінку та вимірювання компонентів структури професійної компетентності майбутніх психологів проведено з урахуванням визначення цього поняття та підходів до його дослідження.

Для визначення місця, ролі та ваги кожного компонента, що можуть виступати як детермінанти цього процесу, був проведений фракторний аналіз методом головних компонентів із Varimax raw обертанням. На основі факторного аналізу розкрито психологічну структуру профресійної компетентності: мотиваційно-ціннісний, операційно-конативний, емоційно-регулятивний і рефлексивно-когнітивний компоненти.

Найбільше смислове навантаження отримав мотиваційно-ціннісний фактор, до складу якого увійшли показники, що відображають смисложиттєві та кар'єрні орієнтації, прагнення до успіху й самореалізації в майбутній профресії. До другого фрактора - операційно-конативного - увійшли показники, що відображають прагнення до змін. Третій фактор - емоційно-регулятивний - відображає емоційно-вольову активність студента, що включає показники емоційного інтелекту та саморегуляції особистості у нових ситуаціях. Четвертий факторкогнітивно-рефлексивний - включає інтелектуальну залученість у прочес оволодіння майбутньою професійною діяльністю через інтерес до знань, моделювання та планування своєї діяльності на основі наявних знань і відкритість до набуття нових знань.

Ключові слова: професійна компетентність, майбутні психологи, мотиваційно-ціннісний, операційно-конативний, емоційно-регулятивний, рефлексивно-когнітивний компоненти, психологічна структура.

\section{Перегончук Наталия. Психологическая структура профессиональной компетентности будущих психологов}

\section{АННОТАЦИЯ}

В статье представлено эмпирическое исследование психологической структуры профессиональной компетентности будущих психологов. 
Охарактеризовано развитие профессиональной компетентности как динамический процесс мобилизации внешних и внутренних ресурсов в непредсказуемых условиях повседневной жизни. В исследовании приняли участие 546 студентов Винницкого государственного педагогического университета имени Михаила Коцюбинского, Национального педагогического университета имени М. П. Драгоманова и Киевского университета имени Бориса Гринченко.

Оценку и измерение компонентов структуры профессиональной компетентности будущих психологов произведено с учетом определения этого понятия и подходов к его исследованию.

Для определения места, роли и веса компонентов, каждый из которых может выступать в качестве детерминант этого процесса, был проведен факторный анализ методом определения главных компонентов с Varimax raw вращением. На основании факторного анализа раскрыто психологическую структуру профессиональной компетентности: мотивационно-ценностный, операционно-конативный, эмоционально-регулятивный, рефлексивно-когнитивный компоненты.

Наибольшую смысловую нагрузку получил мотивационно-ценностный фрактор. В состав этого фактора вошли показатели, отражающие смысложизненные и карьерные ориентации, стремлением к успеху и самореализации в будущей профессии. Ко второму фактору-операционно-конативному - отнесены показатели, отражающие стремление к переменам. Третий фрактор - эмоционально-регулятивный - отражает эмоционально-волевую активность студента, включая показатели эмоционального интеллекта и саморегуляции личности в новых ситуациях. Четвертый фактор - когнитивно-рефлексивный - включает интеллектуальную вовлеченность в процесс овладения будущей профессиональной деятельностью из-за интереса к знаниям, моделирование и планирование своей деятельности на основании имеющихся знаний и открытость к приобретению новых знаний.

Ключевые слова: профессиональная компетентность, будущие психологи, мотивационно-ценностный, операционно-конативный, эмоционально-регулятивный, рефлексивно-когнитивный компоненты, психологическая структура. 